\title{
Middle Manager's Commitment to Change: a Qualitative Study
}

\author{
Evi Kurniasari Purwaningrum \\ Doctoral Students Faculty of \\ Psychology University of Airlangga \\ Lecturer Faculty of Psychology \\ University of 17th August 1945 \\ Samarinda \\ evi.kurniasari2003@gmail.com
}

\author{
Fendy Suhariadi \\ Airlangga University, Faculty of \\ Psychology \\ fendy.suhariadi@psikologi.unair.ac.id
}

\author{
Fajrianthi \\ Airlangga University, Faculty \\ of Psychology \\ fajrianthi@psikologi.unair.ac.id
}

\begin{abstract}
In times of change, it is very important for middle managers to commit to change because middle managers have a strategic role in the formulation and implementation of change. This study aims to explore the middle manager's commitment to change at the beginning of the change period and one year after the initiation of change. This research uses a phenomenological qualitative approach and the longitudinal method. Data was taken using semi-structured interviews at nine middle managers. The result shows three main themes: (1) Middle managers' initial commitment to change is influenced by their views on the importance of change and middle managers experience at the beginning of change, (2) there is a change in commitment to change after one year of organizational change, (3) factors that are influenced change in middle manager's commitment to changes. The findings in this study are expected to be a meaningful contribution to understanding the commitment to change among middle managers.
\end{abstract}

Keywords: Organizational changes, agents of changes, qualitative study.

\section{Introduction}

Now the organization must change with incredible speed (Piderit, 2000), but not all organizational changes are successful, two third failed to change initiative (Sirkin, Keenan \& Jackson, 2005). Nohria and Beer (2000) express the same thing; at least $70 \%$ of all initiatives for change have failed. The inability of managers to overcome the demands of organizational change is a common factor that causes the failure of implementation of change (Huy, 2002). Lack of middle manager commitment will also accelerate the failure of change initiatives (Duck, 200I).

It is very important for organizations to build trust and positive attitudes for individuals to make the changes run successfully (Elias, 2009), especially building a commitment to organizational 
change. Commitment to change is an individual's attitude to change, which Herscovitch and Meyer (2002) defined as a mindset that binds someone to succeed change. Commitment to change is divided into three dimensions, namely affective commitment to change, normative commitment to change, and continuous commitment to change. These differences are based on an individual's motivation to commit to change. Affective commitment to change based on the belief that these changes have benefits for the organization and employees, normative commitment to change commitments based on feeling obliged to provide support for change, continuous commitment to change based on fear of losing certain things if they do not support change.

Herscovitch and Meyer (2002) and also Meyer, Srinivas, Lal \& Topolnytsky (2007) in their study, found that commitment to change is high correlated with behaviors that support successful change. To build employees' commitment to change, a middle manager must commit to change, because they act as a role model for the employees. Abrell-Vogel and Rowold (2014) demonstrated that leaders as role models at the time of the change would improve the commitment to change of the employees if the leader has a high commitment to change. Also, the position of middle managers is close to employees, so they can influence employees to support the implementation of change (Herzig \& Jimmieson, 2006).

A middle manager has an important role during a change effort (Wooldridge, Schmid \& Floyd, 2008; Currie\& Procter, 2005), a middle manager has a role as an agent of change and also as a recipient of change (Giangreco \& Peccei 2005; McConville, 2006). As recipients of change, middle managers must implement changes. Besides their role as agents, middle change managers are expected to influence the change targets so that employees make decisions in accordance with the direction of change (Floyd \& Lane, 2000). As a supporter, managers are expected to be able to exemplify employees in implementing change. As a communicator, during times of change, employees need clear information about the change. Therefore middle managers are expected to be able to communicate changes clearly to them. As a trainer, during the change period, middle managers guide employees to adjust to changes and prepare employees to be able to follow changes. As a mediator, the middle manager is a mediator between the organization and 
employees, that is, the middle manager explains the information that comes from the top management related to the changed policy besides the middle manager also expresses the opinion of the employee regarding changes to top management. And as a manager of resistance, the middle manager is the best position to identify barriers and rejection reasons (lonescu, Merut \& Dragomiroiu, 20I4). The role of top managers in the period of change gets a lot of attention and is highlighted, whereas, in the middle manager, his role in change is not represented prominently (Huy, 2002). In addition, there is only a few research on the commitment to change in the middle manager (Westerberg \& Tafvelin, 20I5), especially in Indonesia.

To achieve organizational goals, it is very important for a leader to commit to change (Westerberg, \& Tafvelin, 20I5) because commitment to change must be developed and maintained from time to time by organizations that experience major and continuous changes (Morin et al., 2016). Morin's opinion, et al. (2016) shows that commitment to change is not static, as stated by Neubert \& Wu, (2009) that commitment to change is a dynamic process.

In longitudinal studies conducted by Westerberg \& Tafvelin, (2015), it is known that during the period of change in commitment to change can change. This finding is different from the research of Shin, Seo, Shapiro \& Taylor (2015) that employees whom at the beginning of the period of change have affective commitment to change or normative change commitments tend to maintain their form of commitment. Shin, Seo, Shapiro \& Taylor (2015) also found that affective commitment to change at the beginning of change does not correlate with a later normative commitment to changes. According to Shin, Seo, Shapiro \& Taylor (20I5), this pattern supports the idea of perseverance beliefs; that is, a person tends to maintain an initial or existing belief. The pattern is personal consistency that is someone wants to act consistently.

The explanation above shows that there are differences in findings. Shin, Seo, Shapiro \& Taylor (2015) found that commitment to change at the beginning of change can be maintained if the leader shows information justice and transformational leadership. Whereas, Westerberg \& Tafvelin (2015) found that at the beginning of change, leaders committed to change based on 
different motivations, so they had different forms of change commitment. As the change progresses, the commitment to change go through changes in addition to being based on obligations and based on the desire to succeed in change, so the differences in commitment to change becomes unclear.

The existence of different findings in the previous studies (Shin, Seo, Shapiro \& Taylor, 20I5, Westerberg \& Tafvelin, 2015; Morin et al., 2016) encourages researchers to explore whether the commitment to change is static or dynamic. The focus of this research is the middle manager's commitment to change because middle managers are the target of change as well as expected as agents of change. The study also aims to add to the literature on the commitment to change to leaders, especially middle-level leaders, because previous studies did not examine this factor (lonescu, Merut \& Dragomiroiu, 2014; Huy, 2002). The focus is on the commitment to change in middle-level managers, while middle managers act not only as recipients of change but also are expected to be agents of change. Researchers used longitudinal qualitative methods because qualitative approaches may reveal aspects that may not be revealed in traditional survey studies, which are commonly used in studies of commitment to change (Westerberg \& Tafvelin, 2015). Jaros (2010) suggested a longitudinal study to uncover how commitment to change changes during the change process within the organization or workplace.

This research uses qualitative methods to get a deeper explanation. And also to understand how commitment changes during the change process, this study will use longitudinal studies. The research questions are:

- How did middle managers perceive changes that occur in the organizations where they work in, and whether the middle manager's views on change affect their commitment to change during the initial period of change?

- After experiencing changes in early change, is there any changes on the middle manager's commitment to change one year later?

- What are the factors that affect the middle manager's commitment to change? 


\section{Method}

This research uses a qualitative method with phenomenology approach. Phenomenological studies describe the general meaning of some individuals to their various life experiences with concepts or phenomena (Creswell, 2015). The focus of this study is to answer the question of how middle managers interpret the commitment to change in organizations that are undergoing a change process?

Participants of this study amounted to nine people, approached through purposive sampling. Participants were selected based on the following characteristics: (I) Middle managers who have occupied the position at least I year, defined by middle managers here in accordance with the definition of Currie \& Procter (200I) that is, managers who hold positions between the highest and lowest levels of work to mediate, negotiate, and interpret the relationship between institutional (strategy) and technical organization (operational), (2). Feeling the impact of the changes that are taking place in the organization they work for. From the interviews, the changes felt by participants include restructuring, work processes, policy changes, technological changes, departmental mergers.

\section{Demographic Overview of Participants}

The study participants came from one of the SOEs in Indonesia that was undergoing organizational changes. After the formation of a holding company, many changes occur as part of the transformation of corporations and strengthen the role of holding strategic function. In addition, changes are made in response to an increasingly dynamic and competitive external environment.

Participants in this study differ in terms of employment, tenure, position, age, and department. Participants I (SI) gender male, age 26 years, bachelor degree, occupy the position of supervisor in the department of human resources development for one year. Participant 2 (S2) female gender, 36 years old, master degree, occupy the position of head of a department in welfare department and industrial relations for two years. Participant 3 (S3) male gender, age 
50 years, high school education, occupies the position of head of a department in human resource development for four years. Participant 4 (S4) male gender, 3-years diploma, occupy a position of department head of the laboratory department for five years. Participant 5 (S5) female gender, age 25 years, bachelor degree, occupy the position of supervisor in the department of innovation and management development for one year. Participant 6 (S6) female gender, age 31 years, master degree, occupy the position of supervisor in the department of education and training management for two years. Participants 7 (S6) female gender, age 5I years, bachelor degree, occupy the position of LSP chairman level with manager position for one year. Participant 8 (S8) male gender, age 54 years, bachelor degree, occupies a position of department head in operation department for six years. Participant 9 (S9) male gender, age 53, 3-years diploma, occupying supervisor position in the operating department for seven years.

\section{Data Collection}

All participants were informed that the interview was intended for research, and previously, participants were asked to be willing to participate in the study. And also explained the participation in the study was voluntary, they could stop the interview at any time and not participate further. Interviews were conducted in the workplace of participants, recorded and transcribed verbatim. One year later, the participants were again contacted and asked to be willing to interview using the same procedure as the previous interview.

The type of interview conducted is a semi-structured interview. To ensure that participants experience the effects of the change, they were asked to explain what organizational changes are ongoing and the effect of those changes on their work. The next question is how the participants perceive the changes that are happening where they work. They were also asked to describe their experience as middle managers in the early days of the change. The second interview was conducted a year later; they were asked questions about how participants perceive the ongoing changes in their workplace. They were also asked to describe the experience as a middle manager during a period of change within a year. 


\section{Data analysis}

The stages of data analysis are carried out in the following steps: the appreciation of transcripts and initial recording, emergent theme formulation, superordinate theme formulation, interparticipant case / interpersonal patterns (La Kahija, 20I7). This study using the review and question and answer procedures with colleagues and checking the data which researchers obtained through group forum to participants to test the validation.

\section{Result}

Upon the analysis, the three superordinate themes emerge: (I) Middle managers' initial commitment to change is influenced by their views on the importance of change and their experience at the beginning of change (2) There is a change in commitment to change in middle managers after one year of organizational change, and (3) Factors affecting change commitment to change in middle managers.

"Middle managers' initial commitment to change is influenced by their views on the importance of change and their experience at the beginning of change."

In the initial interview, we found a common understanding of the reasons for the change in the organization where they work. The same understanding they get after the socialization of the board of directors about the changes that will occur in the company. Almost all participants stated that organizational change cannot be avoided and must be done because the changes that occur are the business of the company to adapt to a dynamic and increasingly competitive environment. Currently, the company is facing a difficult situation resulting from environmental stress. Companies must make changes if they want to survive and compete. Another theme is the middle manager interpreted the company is experiencing a transition period and has not established a strategy to deal with change, and the changes that occur today are different from previous changes. 
Regardless of the understanding and meaningful understanding of the changes that occur in the company where they work, middle managers express different feelings and respond to them differently. Some middle who feel the doubt but then interpreted it as a positive thing for him as delivered by (SI):

"I am open minded if it is about changes and understanding the current condition, but now we are in transition. What we have in mind are some questions, for instance, regarding strategies being used, how the coordination is. And while the changes are in progress, there are extra works for me to do, but not that significant, anyway, because I am used to working overtime. The key is to be able to working efficiently and effectively and to be able to adapt quickly. I feel challenged since I have to learn many new things" (SI)

Besides SI, the positive feelings expressed by participants such as feeling challenged, getting a positive effect from the changes, gaining benefits from the change are reflected in the statement of the four participants below:

"I see many great benefits for the companies if changes have to be done. Thus, I support it..." (S4); "The changes happening are challenges, and from it I have learned many things, I hope my competence will be improved ...." (S5); "Changes are needed badly nowadays and are such a positive decision for the company ...." (S8); "I feel I am being challenged because I usually just make tedious jobs ...." (S9)

Some middle managers felt negative emotions at the beginning of the changes, such as depressed, angry, annoyed, feeling overwhelmed, confused, and uncomfortable. This is illustrated by the statement of four middle managers as follows:

"Changes cannot be done easily. Moreover, it is being done in quick pace and being unstable, I feel unsettled and worried as well...." (S2); "These changes are quite hard for me, it takes my time and gives me sleep problem ...." (S3); "I often feel peeves, angry, make grumblings to 
myself because the changes give me burden, my working load is heavier and make me puzzled" (S6); "The changes are confusing, heavy and make me feel uneasy ......" (S7).

Differences in feelings toward change are caused by how those changes affect their work and how that change touches them personally. As expressed by S6, the changes that affect his work, he gets a lot of workloads, short deadlines, and many tasks come to him outside his main task (which is by the KPI). He also often experienced role conflict, feeling wobbled by change because he has been feeling that he did not get clear guidelines for performing new tasks outside his main tasks.

"While changes are in progress, my burden is heavier; I get extra jobs besides my main jobs, that is because I am a member of team strategy who is involved in conducting studies on the changes. There are many jobs needs to be done besides my main jobs, sometimes I get confused which one I have to do first. That is getting worse when those jobs demand to be finished at the same time. Thus, I feel irritated, I am grumbling, but I try finishing all my jobs ......" S6

The middle managers choose to keep performing the tasks they are responsible for, adjust to change and try to accept the change, regardless of how the middle manager views change, whether it has a positive outlook or a negative outlook on change. From the middle managers' answers in the interview found sub-themes: trying to help the company get through change by working efficiently, changing the mindset to be more positive in assessing change, learning more to adjust to change, helping subordinates and colleagues to adjust to change, socializing changes to subordinates, consistently running changes.

All participants claim to support change by carrying out tasks as a consequence of organizational change, but there are different reasons why they support change. Participants SI, S4, S5, S7, S9 states the reasons that make them support the success of change is a benefit to the company that is achieving goals change and also benefits for yourself. Clearly illustrated in their statement below: 
"Changes make me learn many things and feel excited. I often work overtime because I want this change to be a success. I have empathy on the current condition of this company" SI; "I support these changes because it comes from my conscience. I am a part of this company, and it is amazing for me if I can be useful for this company...." S4; "Changes are positive things for the company..... I try my best to be flexible when changes happen, which is doing every job excellently...." S5; ".....Even if it is hard for the first time, this company is my home....., I am happy that changes will make this company is not stuck in one place. I hope I can be of help to make this company better" S7; I have worked here for some decades now........ Therefore, I have emotional bonds with this company....., I do not want this company to fall because of its incapability of facing changes" S9.

Participant S2, S3, S6, S8 state the reasons for the obligations and responsibilities that make them support change. This is reflected in their statement:

"....., want it or not, like it or not, I have to follow the changes because I am an example for my subordinates" S2; "....what else I can do, Ma'am? That is such an obligation no matter if it is hard or easy... It has to be done, more importantly, because the company is in a difficult situation. Thus, I have to give the best support in these changes... "S3; "Trying to accomplish such changes is a part of my obligation, and there is no other option except doing it...." S6; "My position as a senior staff makes me be an example to my subordinates, following the changes is my obligation"S8.

According to the component of commitment to change stated by Herscovic and Meyer (2002), S4, S5, S7, S9categorizedas having affective commitment to change, as they support for change is motivated by their belief that the change has an advantage. Middle managers (SI, S4, S5, S7, 59) see the changes that occur have benefits for the company and them personally. Affective commitment to change develops because it involves the affection side of the closeness of feelings that individuals have toward the goals of organizational change (Herscovitch \& Meyer, 2002). Middle managers (SI, S4, S7, S9) feel strong emotional ties to the organization they work 
in, so are willing to do their best to support the goal of change. Affective commitment is reflected in the statement "empathy on the condition of the company" SI, "flowing from the conscience, feeling part of the company" S4, "has an emotional bond" S9. At S7, although at first, he felt confused, heavy and uncomfortable about change, because he realized that change has good benefits for the organization and employees, he also feels to have a work organization (sense of belonging), then he is happy and supports the change.

The normative commitment to organizational change was motivated by a sense of obligation (Herscovitch and Meyer, 2002). The four participants, namely S2, S3, S6, S8, felt obligated to be a leader. Besides having to carry out his duties, he should be able to set an example to his subordinates. This reason makes them willing to provide support for change. Gellatly, Meyer \& Luchack, (2006) explains the normative commitment has two forms of moral obligations (moral imperative) and obligations based on indebted obligation. The four middle managers, S2, S3, S6, S8 normative commitment, is based on moral obligation (moral imperative) is doing what they believe as what they should do. Besides, it is also based on indebted obligation; what is done is the reward they give to the company that raises them.

There were changes in commitment to change of the middle managers after a year of organizational change.

In the second interview, a year later, a similar theme was found given change, that change is still ongoing and unfinished, but it is getting clearer, thereby reducing anxiety and uncertainty during the change. The other themes are positive feelings related to changes such as changes make me learn a lot and improve competencies (SI, S2, S3, S4, S5, S6), feel proud of being part of change (S7, S8), feel helped change due to more efficient work (S9).

The experience of middle managers during times of change affects their cognitive and affective changes. Cognitive changes such as changes in the way in solving the problem occur on the subject (S2, S5, S9), one example of a statement as follows: 
"I have different perspectives on finishing problems nowadays. Before there are changes happening, I just try to solve problems with the same methods. At the first time, the changes are not easy for me, moreover because it is fast and ever-changing. I feel unsettled because of these changes, and I feel confused. But I have tried to overcome it by making alternatives to the solution. For instance, if something happens, I will try a solution, but if other things happen, I will try other solutions. Basically, I have prepared alternative plans to overcome anything" (S2)

The positive experiences felt by middle managers make them look at change differently and ultimately affect their feelings toward change. The negative emotions that were felt in the first interview were not seen in the second interview, as happened in S6 and S3. As reflected in the following statement:

" ....., while these changes are happening, I gain many experiences. By learning many things, I become more excited to work...." S6; " According to my competency, these changes are more complex than before, and I feel anxious but since my bosses believe in me, and I see that many our youngsters and subordinates look spirited make me feel optimistic to face these changes and believe that we are going to success" (S3).

Cognitive and affective changes experienced by the middle manager related to the commitment to change, the perceived good benefits of changing the way of thinking and the form of more positive emotions make their reasons for implementing change to be different. S2, S3, S6 in the first interview stated that implementing the change because of the obligation in interviewing two different things, that is besides because the obligation also because of internal motivation and positive emotion felt at the time of doing change as can learn (S2), passionate and optimistic (S3), (S6).

"I realize more that these changes are beneficial personally or corporately, thus now I do not feel only being obliged but also feel that I am in a learning process" (S2) 
"I am a role figure for my subordinates, but currently it is me who has been being inspired. That makes me enjoy my works, and I am no longer feeling forced. Moreover, I want these changes to succeed, make this company move forward" (S3)

"After gaining many experiences, learning many things makes me feel motivated and makes me realize that changes are important. Therefore, I do not feel forced to be involved in such changes" (S6)

Factors that influenced the change in commitment to changes in the middle manager

Several themes were found on the same factors affecting the change in commitment to change in the middle manager. The same factor expressed by the nine middle managers is the reason for the change. Changes initiated by the organization are caused by unavoidable external environmental pressures, the company has no choice but to change. The factors causing these changes make middle managers understandable and ultimately, a driving force for them to be involved and responsible for the success of the change. Another factor is that companies often provide clear and transparent information related to change, whether it be a change objective, a change strategy, or something else. The company also conducts training related to change to make them more confident in the face of change.

The sense factor of having an organization is reflected in the statement of five middle managers (SI, S2, S4, S6, S7, S9) that they have strong emotional ties to the organizations they work for, the firms that raise them, and they want this company to be more advanced and growing. While on the role factor as a middle manager, three participants (S2, S3, S8) said that as a middle manager, they are an example for their subordinates, so it must support change. Other factors that influence commitment to change according to middle managers are leader factors which include: superior leadership (revealed SI, S3, S4, S5, S6, S8), good relationship with superior (revealed by S7, S3), feel always involved in decision making by superiors(revealed by S6, S7). 


\section{Discussion}

Commitment to change is not only an outcome but also a process (Westerberg \& Tafvelin, 2015). Commitment to change is not formed just like that, but through an internalization process (Conner \& Patterson, 1982). Statement of Westerberg and Tafvelin, (2015) and Conner and Patterson, (1982) show that achieving commitment requires a process and commitment to change can change, so is not a stable mindset. In the interview, it was found that after the socialization of middle managers has the same knowledge, that change for the company is important, but during the process of change, they experience different things. This makes their feelings towards the changes are also different. During the process of change, people also make an assessment and consideration of what they know, what they experienced, and what they feel. This assessment is influenced by cognitive and emotional. From here arises change in mindset that organizational change should be supported, although to support those changes are caused by different reasons and factors that vary by each individual.

In the first interview found dimension affective commitment to change and normative commitment to change, however, in the second interview (one year later), in the second interview (one year later) it became difficult to distinguish between affective commitment to change and normative commitment to change. The experience they felt during times of change affect changes in cognitive and affective. The benefits of the changes that they feel either change the way of thinking and to feel positive emotions during the change into the reason middle managers implementing change to be different, that is not only for reasons of liability (normative) but also the reasons the benefits can be felt and perceived in positive emotions (affective). The study is in line with results research from Westerberg and Tafvelin (20I5) commitment to change develops over time and during organizational change.

Even though there is any changes form a commitment to change tends to be maintained. From the results of the first interview, found that middle manager has an affective commitment to change, and there is also a normative commitment to change. Commitment to change on the middle manager is still maintained from time to time, despite there are changes in the form and 
level of commitment. The level of commitment to change is not measured in this study. The results of this study support the research of Shin, Seo, Shapiro \& Taylor (20I5), during the period of change commitment to changes tend to be maintained over time.

Changes on the commitment to change are influenced by factors such as organizational support training to improve competence, clear and transparent information, a good relationship with the boss, leadership, participation in decision-making, emotional attachment to the company and the reason for the change. These factors lead to positive changes in cognitive and affective, which in turn affect changes in the form of a commitment to change in the middle manager. In his research Shin, Seo, Shapiro\& Taylor(2015) found it to maintain a commitment to change to be stronger during organizational change the leaders have to show transformational leadership and provide fair and transparent information. The factors that cause changes in the form of external environmental pressures are also aligned with the research conducted by Jing, Lin \& Ning (20/4). External factors positively influence affective commitment to change and normative commitment to change. This can be explained because employees can understand that external factors are something that cannot be avoided by the organization so that external reasons are more acceptable and have greater legitimacy. Involvement in decision making is a way to stimulate support for a change, is in line with research Van der Voet et al., (2015) and Rogiest, Segers \& Witteloostuijn, (2015). Another important factor is competence, the middle manager felt that the changes perceived competence are now demanding more, so this makes them doubt whether they can pass the changes. This is in line with a research of Izzati, Suhariadi \& Hadi (2016) competence as a factor affecting commitments.

In this study, there are two components of commitment to change found in middle managers; it is likely influenced by the organizational form factor, which is that the company is state-owned with low turnover level. In addition to that of the interview also found a strong sense of organization and the cause of the change is the reason every participant in this study. Another reason is in some studies found no difficulty in distinguishing dimension of commitment to change. In the study of Meyer, Srinivas \& Topolnytsky (2007), a sample of Canadian employees sees normative commitment to change as a 'cost' will occur if they violated so somewhat that 
was similar to a continuous commitment to change. In contrast to Chen and Wang's (2007) study, a sample of China employees sees normative commitment to change as 'morally pure' so it can be distinguished from continuous commitment to change. In the study of Meyer, Srinivas \& Topolnytsky (2007), the dimensions of affective commitment for change and normative commitment to change is rather difficult to distinguish among Indian sample.

\section{Conclusion}

The findings of this study indicate that middle managers' initial commitment to change is influenced by their views on the reasons for change and the importance of change for the organization. Besides, it is also influenced by the middle manager experience at the beginning of changes. Also, it was found that there is a change in the form of change commitments based on reasons for supporting change. Middle managers who are initially committed to change due to liability factors feels the benefits of organizational changes during the middle process of changes that one year later it becomes difficult to distinguish between normative changes and affective commitment to change.

Changes commitment to change is influenced by factors such as organizational support training to improve competence, clear and transparent information, a good relationship with the boss, leadership, participation in decision-making, emotional attachment to the company and the reason for the change. These factors lead to positive changes in cognitive and affective, which in turn affect changes in the form of a commitment to change in the middle manager. If the organization wants to develop and maintain a change commitment on the middle manager, the organization should pay attention and fulfill these factors.

This study has limitations that are implemented in an organization with a limited number of respondents. Subsequent research can be done on the middle managers from the diverse organization. This study can also be followed by a quantitative method to generalize the results. 


\section{Reference}

Abrell-Vogel, C., \& Rowold, J. (20I4). Leaders' commitment to change and their effectiveness in change-a multilevel investigation. Journal of organizational change management, 27(6), 900 921.

Chen, J., \& Wang, L. (2007). Locus of control and the three components of commitment to change. Personality and Individual Differences, 42(3), 503-5I2.

Conner, D., R., \& Patterson, R.W. (1982). Building commitment to organizational change. Training \& Development Journal,36, 18-30.

Creswell, John W. (20I5). Penelitian Kualitatif \& Desain Riset. Yogyakarta : Pustaka Pelajar.

Currie, G., \& Procter, S. (200I). Exploring the relationship between HR and middle managers. Human Resource Management Journal, II (3), 53-69.

Currie, G., \& Procter, S. J. (2005). The antecedents of middle managers' strategic contribution: The case of a professional bureaucracy. Journal of Management Studies, 42: 1325- 1356.

Duck, J. D. (200I). The change monster: The human forces that fuel or foil corporate transformation and change ( $I^{\text {st }}$ ed.). New York: Crown Business.

Elias, S. M. (2009). Employee commitment in times of change: Assessing the importance of attitudes toward organizational change? Journal of Management, 35(I), 37-55.

Floyd, S. W. \& Lane, P. J. (2000). Strategizing throughout the organization: Managing role conflict in strategic renewal. Academy of Management Review, 25, I54-I77.

Gellatly, I.R., Meyer, J.P., Luchack, A.A. (2006). Combined effects of the three commitment components on focal and discretionary behaviors: A test of Meyer and Herscovitch's proportions. Journal of Vocational Behavior, 69, 33I-345.

Giangreco, A., \& Peccei, R. (2005). The nature and antecedents of middle manager resistance to change: Evidence from an Italian context. The international journal of human resource management, I6(10), 1812-1829.

Herscovitch, L., \& Meyer, J. P. (2002). Commitment to organizational change: extension of a three-component model. Journal of Applied Psychology, 87(3), 474-486.

Herzig, S. E., \& Jimmieson, N. L. (2006). Middle managers' uncertainty management during organizational change. Leadership \& Organization Development Journal, 27(8), 628-645.

Huy, Q. N. (2002). Emotional balancing of organizational continuity and radical change: The contribution of middle managers. Administrative Science Quarterly, 47(I), 3 I-69.

lonescu, E. I., Meruță, A., \& Dragomiroiu, R. (20I4). Role of managers in management of change. Procedia Economics and Finance, 16, 293-298.

Izzati, U. A., Suhariadi, F., \& Hadi, C. (2016). The role of self competence on affective commitment of vocational high school temporary teacher. International Journal of Organizational Innovation (Online), 8(4), 133. 
Jaros, S. (2010). Commitment to organizational change: A critical review. Journal of Change Management, 10(I), 79-108.

Jing, R., Lin Xie, J., \& Ning, J. (20/4). Commitment to organizational change in a Chinese context. Journal of Managerial Psychology, 29(8), I098-I I I 4.

La Kahija, Y.F. (2017). Penelitian fenomenologis : Jalan memahami pengalaman hidup. Yogjakarta : PT Kanisius.

McConville, T. (2006). 'Divolved Responsibilities, Middle Managers and Role Dissonance'. Personnel Review, 35(6) 637-653.

Meyer, J. P., Srinivas, E. S., Lal, J. B., \& Topolnytsky, L. (2007). Employee commitment and support for an organizational change: Test of the three-component model in two cultures. Journal of Occupational \& Organizational Psychology, 80(2), I85-2II.

Morin, A. J., Meyer, J. P., Bélanger, É., Boudrias, J. S., Gagné, M., \& Parker, P. D., (2016). Longitudinal associations between employees' beliefs about the quality of the change management process, affective commitment to change, and psychological empowerment. Human Relations, 69(3), 839-867.

Neubert, M., and Wu, C. (2009). Action commitments, in H. Klein, T. Becker, and J. Meyer (eds) Commitment in Organizations: Accumulated Wisdom and New Directions, pp. I8I-2I0 (New York: Routledge.

Nohria, N. \& Beer, M. (2000). Cracking the code of change. Harvard Business Review, 78(3), I33|41.https://hbr.org/2000/05/cracking-the-code-of-change

Piderit, S. (2000). Rethinking resistance and recognizing ambivalence: A multidimensional view of attitudes toward an organizational change. Academy of Management Review, 25, 783794.

Rogiest, S., Segers, J., \& van Witteloostuijn, A. (20I5). Climate, communication, and participation impacting commitment to change. Journal of Organizational Change Management, 28(6), 1094-I 106.

Seo, M. G., Taylor, M. S., Hill, N. S., Zhang, X., Tesluk, P. E., \& Lorinkova, N. M. (20I2). The role of effect and leadership during organizational change. Personnel Psychology, 65(I), $121-165$.

Shin, J., Seo, M. G., Shapiro, D. L., \& Taylor, M. S. (20I5). Maintaining employees' commitment to organizational change the role of leaders' informational justice and transformational leadership. The Journal of Applied Behavioral Science, 50 I-528.

Sirkin, H. L., Keenan, P., \& Jackson, A. (2005). The hard side of change management. Harvard Business Review, 83(10), 108.

Van der Voet, J., Kuipers, B. S., \& Groeneveld, S. (20I5). Implementing change in public organizations: The relationship between leadership and affective commitment to change in a public sector context. Public Management Review, 18(6), 842-865. 
Westerberg, K., \& Tafvelin, S. (20I5). Changes in commitment to change among leaders in home help services. Leadership in Health Services.

Wooldridge, B., Schmid, T., \& Floyd, S. W. (2008). The middle management perspective on the strategy process: Contributions, synthesis, and future research. Journal of management, 34(6), II90-I22I. 